\title{
Monetary Policy Transmission Channels and Economic Growth in Nigeria
}

\author{
Iwedi Marshal \\ 'Department of Banking and Finance, Rivers State University, Nigeria. \\ Email:iwedimarshal@yahoo.com Tel:+2348038735422
}

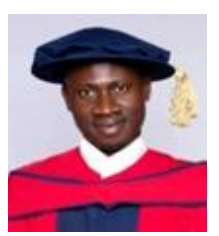

\begin{abstract}
This study empirically analyzes monetary policy transmission channels and economic growth in Nigeria using the vector auto regression model. Time series data were used for the period of 56 years (1960 to 2016) and sourced from the Central Bank of Nigeria statistical bulletin for various issues. The analyses show a good number of findings. Firstly, the unit root test results shows that all the variables of transmission channels are non-stationary at level, but appear stationary at first difference. Hence, the series are all integrated of order I (1). This of course authorized the study to proceed with the co-integration test which revealed that there is a long run relationship between monetary policy transmission channels and economic growth in Nigeria. Following the fact that the variables under study are co-integrated, the study went further to estimate the vector autoregressive model. The baseline result of the vector autoregressive model indicates that there exist a significant positive short run relationship between the channels of monetary policy transmission and macroeconomic output in Nigeria. Therefore, we conclude that interest rate and credit channels are critical channels for transmitting monetary policy impulses into the Nigeria economy. Based on this, the study recommends among others that the Nigeria monetary authority should as a matter of policy encourage and emphasize the good management of the transmission channels and this should be vigorously pursued, as it has the ability to trigger growth of the Nigeria economy.
\end{abstract}

Keywords: Monetary policy, Keynesians, Monetarist, Interest rate channel, Credit channel, Economic growth.

JEL Classification: E52; E12; E59; E49; E60.

Citation | Iwedi Marshal (2019). Monetary Policy Transmission Channels and Economic Growth in Nigeria. Asian Journal of Economics and Empirical Research, 6(2): 93-100.

History:

Received: 13 May 2019

Revised: 18 June 2019

Accepted: 29 July 2019

Published: 5 September 2019

Licensed: This work is licensed under a Creative Commons

Attribution 3.0 License $($ (c) $)$

Publisher: Asian Online Journal Publishing Group
Funding: This study received no specific financial support.

Competing Interests: The author declares that there are no conflicts of interests regarding the publication of this paper.

Transparency: The authors confirms that the manuscript is an honest, accurate, and transparent account of the study was reported; that no vital features of the study have been omitted; and that any discrepancies from the study as planned have been explained.

study as planned have been explained.
Ethical: This study follows all ethical practices during writing.

\section{Contents}

1. Introduction

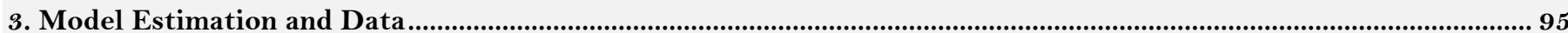

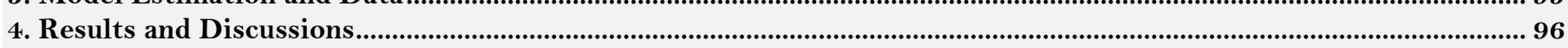

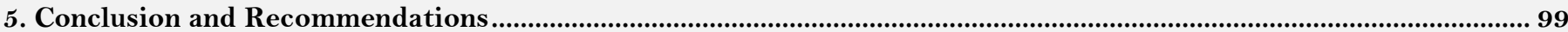

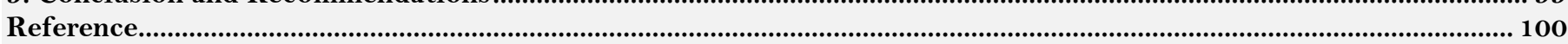




\section{Contribution of this paper to the literature}

This study contributes to existing literature by examining monetary policy transmission channels and economic growth in Nigeria.

\section{Introduction}

Over the decades, the real effect of the transmission channels of monetary policy on the economy has been a contentious area of debate in the academic literature (Bernanke and Gertler, 1995). This is because the argument among scholars about the channel through which monetary policy actions can be transmitted into the economy to achieve some selected macroeconomic goals is still yet to be ascertained. Some schools of thought believe and support the interest rate channel as the channel for transmitting monetary policy action while other scholars support and believe that the credit channel is the answer. The monetary policy transmission channel is the processes by which changes in monetary policy decision affect the rate of economic activity (Taylor, 1995). However, it has been discovered that the monetary policy transmission works through various channels such as the exchange rate channel, the interest rate channel, the bank credit channel and the assets price channel to affect different markets, institutions, sectors at different speeds and intensities (Cecchetti, 1999; Mihov, 2001; Ganev et al., 2002; Kujis, 2002; Elbourne et al., 2003; Juks, 2004; Nwosa and Saibu, 2012; Ishioro, 2013; Ndekwe, 2013; Hassan, 2015).

Despite the efforts and measures taken by the nation monetary authority $(\mathrm{CBN})$ in recent times, the uncertain nature of the transmission mechanism and poor understanding of the system has remained a major challenge for monetary policy (Uchendu, 2009). Nigeria as an economy has adopted different monetary policy regimes with the view that the economy will response favorably, but the poor performance of the economy in recent times further suggests that the lofty objectives of monetary policy may have been negatively affected by the inadequate knowledge of the exact channel through which monetary actions transmits to the economy.

In the light of the above, however, very limited empirical works of citable significance have studied transmission channels of monetary policy in Nigeria using small data information and different methodologies; however the issue of investigating the true nature of the relationship between interest rate and credit channels of monetary policy transmission in Nigeria is still empirically unstudied and published using large data information and a more sophisticated methodology. From the forgoing, one can easily and clearly identify a lots of research gaps to be bridged and hence the main thrust of this paper is to critically analyze the impact of monetary policy transmission channels on economic growth in Nigeria using large data information from 1960 -2016.

\section{Literature Review}

The review of literature is done in two sub-sections viz: theoretical framework and empirical review.

\subsection{Theoretical Framework}

This paper is anchored on the economic belief of both the Keynesians and the Monetarists schools of thought.

\subsubsection{Keynesians Theory}

The Keynesians theorize the effects of monetary policy instrument on the money market, the investment goods market and the goods and services market. Keynesian transmission mechanism states that, an increase in the money supply lowers the interest rate, which causes investment to rise and the AD curve to shift rightward thereby real GDP increasing and the unemployment rate dropping. Graphically it is represented in Figure 1 as follows:

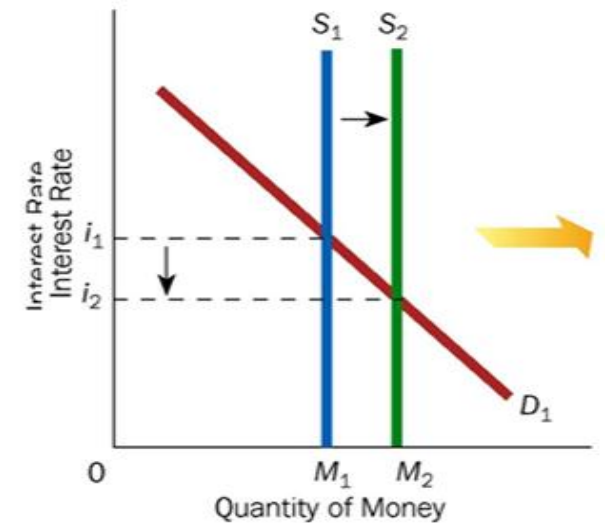

(a)

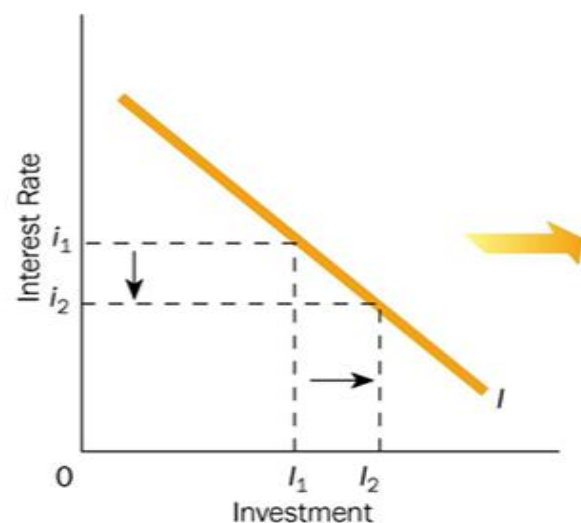

(b)

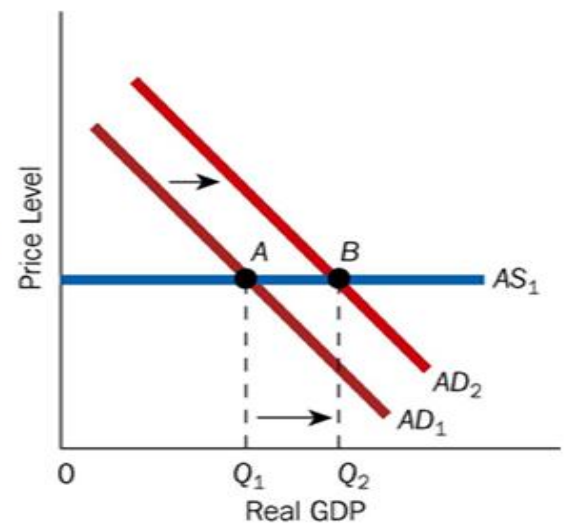

(c)

Goods and Services Market (AD-AS framework)

Source: Jhingan (2011).

Figure-1. Keynesian transmission mechanism.

\subsubsection{Monetarist Theory}

The Monetarist Transmission Mechanism holds that an increase in Money supply: increases in aggregate demand, which causes Real GDP and Price to increase with a fall in Unemployment while a decrease in Money supply leads to a decrease in aggregate demand, Real GDP and Prices with a rise in Unemployment. Graphically it represented as in Figure 2. 


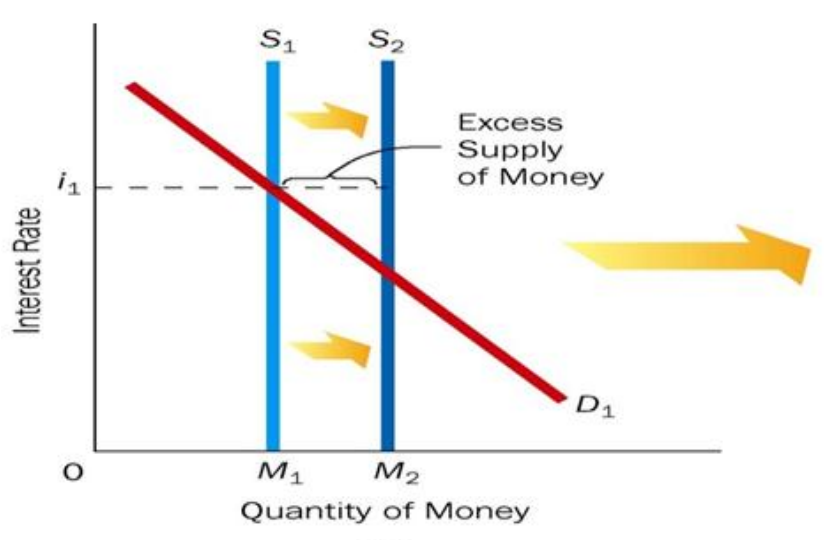

(a)

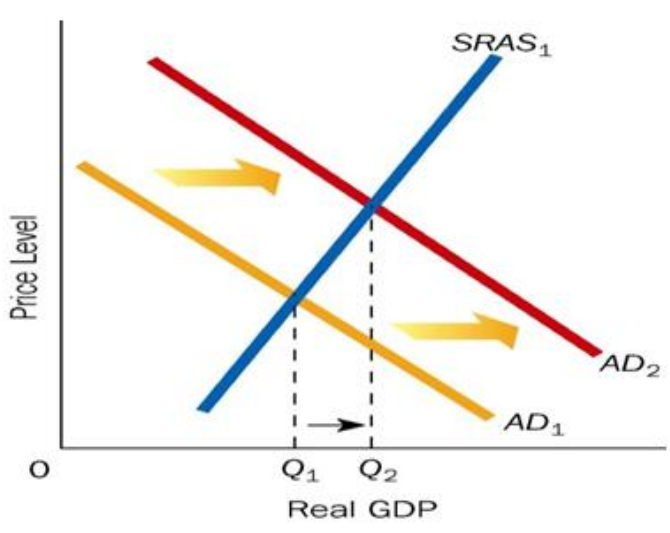

(b)

Goods and Services Market

(AD-AS framework)

Source: Jhingan (2011).

Figure-2. Monetarist transmission mechanism.

\subsection{Empirical Review}

To the best knowledge of the researcher, there were few numbers of available empirical works conducted concerning the transmission channels of monetary policy in the case of Nigeria. For example, Chuku (2009) carried out such a study in Nigeria. The author used quarterly data from 1986Q1-2008Q4 and applies SVAR model in measuring the impact of monetary policy innovations in the country. His paper reveal that money supply (M2) as a quantity anchor has a moderate effect on both output and prices, while the monetary policy rate (MPR) and real effective exchange rate (REER) have neutral effect on output.

Also Nwosa and Saibu (2012) investigated the transmission mechanism of monetary policy impact on the output of different sectors of the Nigerian economy. They however used the VAR methodology and found both the interest rate and exchange rate as the most effective channels of stimulating output growth of most of the sectors in the country. Chimobi and Uche (2010) employed the co-integration technique and causality test to examine the relationship between money and real economic variables in Nigeria. Their study reveals that no long run relationship between money and real economic variables. However, money supply was found to have a causal effect on both output and prices. In contrast, Harcourt et al. (2011) adopting the techniques of Vector Error Correction Model (VECM) and co integration test, found that there is long run relationship among money supply, minimum rediscount rate and treasury bill rate in Nigeria. The study also reveals that while minimum rediscount rate impacts on inflation at lag 2, money supply does not. Fasanya et al. (2013) study show that inflation, exchange rate and external reserves constitutes the most effective tools of monetary policy that promote growth of the Nigerian economy. Ishioro (2013) study examines the channels of monetary transmission mechanism in Nigeria. The study employed the granger causality test and the test shows that three channels of interest rate, exchange rate and the credit channels are functional in Nigeria. Ndekwe (2013) found that the credit channel in the financial market for the supply of credit to private sector gives the greatest effect in the way monetary policy is transmitted to the economy. He also realized that interest rate and exchange rate channels at the period 1981-2008 have weak effect on the real economy. Also, more recently, Ismail (2014) using the same techniques of co integration and VECM during the period of 1975-2010, also found co integrating relationship exists between the monetary policy variables and the real economic variable (RGDP) in Nigeria.

Obafemi and Ifere (2015) investigated the mixed evidence on the effectiveness of monetary policy transmission by exploring the quarterly data of the period 1970 to 2013, tested using the FAVAR model with 53 variables. The results supported that interest rates and credit channels are the dominant and strongest channel of transmission of monetary shocks in Nigeria. While the exchange rate, and stock channel shows weak impact in the transmission process. The study by Omolade and Ngalawa (2017) in Nigeria employed structural variance decomposition approach (SVAR) to examine monetary policy transmission mechanism and manufacturing output growth in Libya and Nigeria. The authors document that exchange rate regime has some influences on the monetary policy transmission and its effectiveness on the manufacturing output growth in the two oil exporting countries.

\section{Model Estimation and Data}

The estimations are carried out on yearly data spanning 1960 to 2016. For Nigeria, the data series cover interest rates channel (monetary policy rate, prime and maximum lending rates and deposit rate, and 90-day T-bills rate), for credit channel it includes credit to the core private sector, credit to the government, credit to SMEs and net domestic credit to the economy, while real GDP was used as the dependent variable in the model specifications.

\subsection{Model Specification}

Following the previous works of Chileshe et al. (2014) we model the monetary policy transmission channels in Nigeria as follow. The first model below is used to capture the interest rate channel while the next captures the credit channel.

$$
R G D P_{t}=f\left(M P R_{t}, T B R_{t} M L R_{t}, P L R_{t}, D P R_{t}\right)
$$

Equation 2 presents the estimable version of Equation 1 .

$$
\begin{aligned}
R G D P_{t}= & \alpha_{0}+\beta_{1} M P R_{t}+\beta_{2} T B R_{t}+\beta_{3} M L R_{t}+\beta_{4} P L R_{t}+\beta_{5} D P R_{t}+\mu \\
= & \alpha_{0}+\sum_{i=0}^{n} \beta_{1,}+E_{i t ;} \beta_{i} \geq 0 \\
& R G D P_{t}=f\left(C P S_{t}, C G O_{t}, N D C_{t}, C S M_{t}\right)
\end{aligned}
$$

Equation 5 presents the estimable version of Equation 4. 
We can rewrite the model of credit channel to have the estimable version in Equation 5.

$$
\begin{aligned}
& R G D P_{t}=\alpha_{0}+\beta_{1} C P S_{t}+\beta_{2} C G O_{t}+\beta_{3} N D C_{t}+\beta_{4} C S M_{t}+\mu \\
& =\alpha_{0}+\sum_{i=0}^{n} \beta_{1,}{ }^{+} E_{i t ;} \beta_{i} \geq 0
\end{aligned}
$$

Where

RGDP = Real Gross Domestic Product Growth Rate.

MPR = Monetary Policy Rate.

MLR = Maximum Lending Rate of Deposit Money Banks.

PLR = Prime Lending Rates of Deposit Money Banks.

TBR = Treasury Bills Rates.

DPR = Deposit Rate of Deposit Money Banks.

CPS $=$ Credit Private Sector.

CGO = Credit to the Government.

NDC = Net Domestic Credit to the Economy.

$\mathrm{CSM}=$ Credit to Small and Medium Enterprises.

$\alpha_{0}=$ Constant $/$ Intercept.

$\beta_{1}-\beta_{4}=$ Coefficients of independent variables.

$\mu_{i t} \quad=$ Error Term.

\section{Results and Discussions}

Table-1.Unit root test for interest rate channel variable.

\begin{tabular}{c|c|c|c|c|c|c}
\hline Items & D(RGDP) & D(MPR) & D(TBR) & D(MLR) & D(PLR) & D(DPR) \\
\hline ADF statistics & -7.727133 & -9.717338 & -8.278697 & -9.721453 & -11.72617 & -8.611123 \\
\hline $1 \%$ & -3.555023 & -3.555023 & -3.555023 & -3.555023 & -3.555023 & -3.555023 \\
\hline $5 \%$ & -2.915522 & -2.915522 & -2.915522 & -2.915522 & -2.915522 & -2.915522 \\
\hline Probability & 0.0000 & 0.0000 & 0.0000 & 0.0000 & 0.0000 & 0.0000 \\
\hline \multicolumn{7}{l}{ Source: E-view 9.0 output. }
\end{tabular}

Table-2.Unit root test for credit channel.

\begin{tabular}{c|c|c|c|c|c}
\hline Items & D(RGDP) & D(CPS) & D(CGO) & D(CSM) & D(NDC) \\
\hline ADF statistics & -7.727133 & -6.479150 & -12.16586 & -9.453190 & -13.03563 \\
\hline $1 \%$ & -3.555023 & -3.555023 & -3.555023 & -3.555023 & -3.555023 \\
\hline $5 \%$ & -2.915522 & -2.915522 & -2.915522 & -2.915522 & -2.915522 \\
\hline Probability & 0.0000 & 0.0000 & 0.0000 & 0.0000 & 0.0000 \\
\hline
\end{tabular}

The study conducted stationarity test using the Augmented Dickey Fuller (ADF) test. The results are summarized and presented in Table 1 and Table 2 for each of the variables studied. From the table displaying the result it is obvious that all the interest rate channel variables and credit channel variables were non stationary at levels but appears stationary at first difference. Hence, the series are all integrated of order I (1). This is evidence by the fact that the absolute values of the ADF test statistics are all greater than the MacKinnon critical values at $1 \%$ and $5 \%$ level of significance and thus the respective null hypotheses of non-stationarity are rejected, implying

\begin{tabular}{|c|c|c|c|c|c|c|}
\hline Items & RGDP & MPR & TBR & MLR & PLR & DPR \\
\hline Lag 1 & $\begin{array}{c}0.601772 \\
(0.14616) \\
{[4.11721]}\end{array}$ & $\begin{array}{l}1.362664 \\
(1.49336) \\
{[0.91248]}\end{array}$ & $\begin{array}{c}0.227538 \\
(1.00227) \\
{[0.22702]}\end{array}$ & $\begin{array}{c}0.341193 \\
(0.66646) \\
{[0.51195]}\end{array}$ & $\begin{array}{c}-0.056965 \\
(0.61548) \\
{[-0.09255]}\end{array}$ & $\begin{array}{l}0.842714 \\
(0.77346) \\
{[1.08954]}\end{array}$ \\
\hline $\operatorname{Lag} 2$ & $\begin{array}{c}-0.229958 \\
(0.14501) \\
{[-1.58577]}\end{array}$ & $\begin{array}{l}1.199856 \\
(1.67295) \\
{[0.71721]}\end{array}$ & $\begin{array}{c}1.045003 \\
(1.25611) \\
{[0.83194]}\end{array}$ & $\begin{array}{l}0.397281 \\
(0.67848) \\
{[0.58554]}\end{array}$ & $\begin{array}{c}-0.256329 \\
(0.62775) \\
{[-0.40833]}\end{array}$ & $\begin{array}{c}-0.739319 \\
(0.74293) \\
{[-0.99513]}\end{array}$ \\
\hline Constant & $\begin{array}{r}10.93097 \\
(3.78523) \\
{[2.88779]}\end{array}$ & $\begin{array}{l}0.753832 \\
(1.00051) \\
{[0.75345]}\end{array}$ & $\begin{array}{l}0.684720 \\
(1.25215) \\
{[0.54683]}\end{array}$ & $\begin{array}{l}0.947191 \\
(1.48579) \\
{[0.63750]}\end{array}$ & $\begin{array}{l}1.787844 \\
(1.18116) \\
{[1.51363]}\end{array}$ & $\begin{array}{l}1.125876 \\
(1.17772) \\
{[0.95598]}\end{array}$ \\
\hline R-squared & 0.678640 & & & & & \\
\hline Adj. R-squared & 0.529680 & & & & & \\
\hline $\begin{array}{c}\text { F-statistic } \\
\text { Prob } \\
\text { Log likelihood } \\
\text { Akaike AIC } \\
\text { Schwarz SC } \\
\text { Durbin Watson }\end{array}$ & $\begin{array}{c}13.50635 \\
0.000087 \\
-187.9030 \\
7.305563 \\
7.780023 \\
2.078935\end{array}$ & & & & & \\
\hline
\end{tabular}
the absence of unit roots among the variables.

Source: E-view 9.0 output.

A cursory look at Table 3, it can be seen from the result that the coefficient of monetary policy rate (MPR) was positively and not significant related to Real GDP at lag 1 and 2 . The MPR coefficient records a positive value of 1.362664 and 1.199856 with a t-value of 0.91248 and 0.71721 at lag 1 and 2 respectively. This implies that MPR is an important interest rate channel variable that explains future path of Nigeria economic growth. 
Table-4.Variance decomposition analysis for interest rate channel.

\begin{tabular}{|c|c|c|c|c|c|c|c|}
\hline Variance decomposition of RGDP: & & & & & & & \\
\hline Period & S.E. & RGDP & MPR & TBR & MLR & PLR & DPR \\
\hline 1 & 8.434337 & 100.0000 & 0.000000 & 0.000000 & 0.000000 & 0.000000 & 0.000000 \\
\hline 2 & 10.11961 & 96.95490 & 0.005617 & 0.071339 & 0.785662 & 0.392427 & 1.790055 \\
\hline 3 & 10.43453 & 92.96489 & 0.923625 & 2.083647 & 1.190620 & 0.476967 & 2.360251 \\
\hline 4 & 10.65481 & 89.17154 & 2.654280 & 3.571297 & 1.408247 & 0.913575 & 2.281065 \\
\hline 5 & 10.79910 & 86.82970 & 4.562318 & 3.656825 & 1.429113 & 1.301516 & 2.220527 \\
\hline 6 & 10.90015 & 85.25431 & 6.006015 & 3.590357 & 1.437480 & 1.513553 & 2.198282 \\
\hline 7 & 10.98339 & 84.07429 & 7.190904 & 3.536191 & 1.425737 & 1.585936 & 2.186947 \\
\hline 8 & 11.05811 & 83.03592 & 8.201333 & 3.517040 & 1.407892 & 1.680023 & 2.157788 \\
\hline 9 & 11.12375 & 82.10323 & 8.997801 & 3.538194 & 1.392591 & 1.825263 & 2.142924 \\
\hline 10 & 11.18126 & 81.27781 & 9.630680 & 3.572409 & 1.380743 & 1.994862 & 2.143495 \\
\hline \multicolumn{8}{|l|}{ Variance decomposition of MPR: } \\
\hline Period & S.E. & RGDP & MPR & TBR & MLR & PLR & DPR \\
\hline 1 & 2.229357 & 0.962426 & 99.03757 & 0.000000 & 0.000000 & 0.000000 & 0.000000 \\
\hline 2 & 3.201704 & 0.592556 & 77.24688 & 7.065998 & 0.107096 & 11.22560 & 3.761874 \\
\hline 3 & 3.503843 & 1.352799 & 78.62124 & 6.027942 & 1.067849 & 9.762551 & 3.167618 \\
\hline 4 & 3.878872 & 1.634242 & 80.01638 & 5.988309 & 0.935444 & 8.826729 & 2.598899 \\
\hline 5 & 4.173937 & 1.700975 & 78.21249 & 5.786780 & 0.841475 & 10.49983 & 2.958450 \\
\hline 6 & 4.373634 & 1.622943 & 77.38652 & 5.692269 & 0.863504 & 11.39263 & 3.042140 \\
\hline 7 & 4.551176 & 1.542700 & 76.66719 & 5.666532 & 0.901950 & 12.13302 & 3.088602 \\
\hline 8 & 4.701110 & 1.499726 & 76.18800 & 5.548143 & 0.989095 & 12.65834 & 3.116704 \\
\hline 9 & 4.827150 & 1.485237 & 75.99217 & 5.384562 & 1.090249 & 12.96958 & 3.078205 \\
\hline 10 & 4.935917 & 1.487787 & 75.91877 & 5.221370 & 1.198246 & 13.14594 & 3.027884 \\
\hline \multicolumn{8}{|l|}{ Variance decomposition of TBR: } \\
\hline Period & S.E. & RGDP & MPR & TBR & MLR & PLR & DPR \\
\hline 1 & 2.790077 & 0.182549 & 74.08539 & 25.73206 & 0.000000 & 0.000000 & 0.000000 \\
\hline 2 & 4.007012 & 0.198258 & 57.26735 & 31.32728 & 0.701355 & 4.650702 & 5.855063 \\
\hline 3 & 4.328164 & 0.747484 & 60.77545 & 27.61258 & 1.836367 & 3.987794 & 5.040329 \\
\hline 4 & 4.684304 & 0.926509 & 65.06314 & 24.05664 & 1.568509 & 3.822207 & 4.562996 \\
\hline 5 & 4.963857 & 0.911704 & 65.08182 & 21.56190 & 1.623468 & 5.640063 & 5.181042 \\
\hline 6 & 5.145441 & 0.853053 & 65.16276 & 20.11442 & 1.939184 & 6.563966 & 5.366618 \\
\hline 7 & 5.304011 & 0.806471 & 65.33822 & 18.97537 & 2.247383 & 7.216091 & 5.416459 \\
\hline 8 & 5.440150 & 0.782931 & 65.52014 & 18.04100 & 2.610468 & 7.636690 & 5.408772 \\
\hline 9 & 5.555371 & 0.779243 & 65.78101 & 17.30545 & 2.970189 & 7.843952 & 5.320155 \\
\hline 10 & 5.655542 & 0.786133 & 66.03663 & 16.71488 & 3.308435 & 7.932286 & 5.221640 \\
\hline \multicolumn{8}{|l|}{ Variance decomposition of LDR: } \\
\hline Period & S.E. & RGDP & MPR & TBR & MLR & PLR & DPR \\
\hline 1 & 3.310672 & 0.240731 & 68.97141 & 0.468549 & 30.31931 & 0.000000 & 0.000000 \\
\hline 2 & 4.221571 & 1.008619 & 60.77094 & 0.785295 & 20.81065 & 16.60810 & 0.016409 \\
\hline 3 & 4.573026 & 1.057218 & 59.82039 & 3.191765 & 18.13566 & 17.37432 & 0.420651 \\
\hline 4 & 5.185386 & 0.874255 & 55.87862 & 9.363598 & 15.11311 & 17.49793 & 1.272489 \\
\hline 5 & 5.657975 & 0.783283 & 52.92377 & 11.31902 & 12.90277 & 19.89322 & 2.177947 \\
\hline 6 & 5.962704 & 0.759949 & 52.22219 & 12.02319 & 11.66142 & 21.08746 & 2.245790 \\
\hline 7 & 6.222071 & 0.805485 & 52.30239 & 12.41259 & 10.73198 & 21.58651 & 2.161037 \\
\hline 8 & 6.448688 & 0.906820 & 52.71578 & 12.54829 & 10.00220 & 21.76207 & 2.064834 \\
\hline 9 & 6.647557 & 1.015566 & 53.25193 & 12.55158 & 9.420467 & 21.79075 & 1.969709 \\
\hline 10 & 6.824151 & 1.107376 & 53.77078 & 12.52034 & 8.944543 & 21.76533 & 1.891622 \\
\hline \multicolumn{8}{|l|}{ Variance decomposition of PLR: } \\
\hline Period & S.E. & RGDP & MPR & TBR & MLR & PLR & DPR \\
\hline 1 & 2.631887 & 0.244115 & 27.49415 & 0.887946 & 6.481833 & 64.89195 & 0.000000 \\
\hline 2 & 3.138912 & 1.401136 & 31.44379 & 1.795441 & 7.392059 & 53.91792 & 4.049655 \\
\hline 3 & 3.723156 & 1.271320 & 43.35407 & 4.578869 & 5.329843 & 42.58312 & 2.882774 \\
\hline 4 & 4.223003 & 1.455586 & 46.94058 & 5.168531 & 4.333745 & 39.01658 & 3.084971 \\
\hline 5 & 4.564896 & 1.524997 & 50.58178 & 5.230643 & 3.826601 & 36.06926 & 2.766712 \\
\hline 6 & 4.872764 & 1.585287 & 53.16908 & 5.239486 & 3.444569 & 34.01944 & 2.542142 \\
\hline 7 & 5.128340 & 1.644133 & 55.05052 & 5.185666 & 3.208963 & 32.49095 & 2.419771 \\
\hline 8 & 5.347064 & 1.677008 & 56.54160 & 5.117042 & 3.032927 & 31.31165 & 2.319774 \\
\hline 9 & 5.535099 & 1.695508 & 57.66590 & 5.040768 & 2.914516 & 30.42220 & 2.261114 \\
\hline 10 & 5.696536 & 1.703037 & 58.56735 & 4.962703 & 2.834927 & 29.71028 & 2.221704 \\
\hline \multicolumn{8}{|l|}{ Variance decomposition of DPR: } \\
\hline Period & S.E. & RGDP & MPR & TBR & MLR & PLR & DPR \\
\hline 1 & 2.624210 & 0.009943 & 48.58470 & 0.270150 & 2.005392 & 11.64658 & 37.48324 \\
\hline 2 & 3.457687 & 0.135769 & 44.79117 & 1.646227 & 3.278928 & 23.98137 & 26.16654 \\
\hline 3 & 3.877004 & 0.254214 & 45.59682 & 1.424333 & 6.583039 & 23.46897 & 22.67262 \\
\hline 4 & 4.261912 & 0.210638 & 49.45005 & 1.223300 & 7.656603 & 21.38626 & 20.07315 \\
\hline 5 & 4.603639 & 0.228123 & 51.73159 & 1.149316 & 8.690461 & 20.19295 & 18.00756 \\
\hline 6 & 4.873761 & 0.276649 & 53.19055 & 1.385435 & 9.865343 & 18.91768 & 16.36434 \\
\hline 7 & 5.101285 & 0.321693 & 54.50980 & 1.587383 & 10.72062 & 17.75040 & 15.11011 \\
\hline 8 & 5.297389 & 0.352962 & 55.47291 & 1.780755 & 11.39475 & 16.80909 & 14.18953 \\
\hline 9 & 5.463912 & 0.365877 & 56.09549 & 2.001014 & 11.98258 & 16.05494 & 13.50010 \\
\hline 10 & 5.605358 & 0.367229 & 56.46151 & 2.232607 & 12.52078 & 15.44088 & 12.97699 \\
\hline $\begin{array}{c}\text { Cholesky ordering: RGDP MPR TBR } \\
\text { MLR PLR DPR }\end{array}$ & & & & & & & \\
\hline
\end{tabular}

Source: E-view 9.0 output.

On the other hand, coefficient for Treasury bill rate (TBR) was positively and not significantly related to Real GDP of Nigeria at both lag 1 and 2. The TBR coefficient was positive with this value 0.227538 and 1.045003 with a t-value of 0.22702 and 0.83194 respectively at lag 1 and 2 . Again the coefficient of maximum lending rate of deposit money bank (MLR) shows a positive and not significant relationship to Real GDP at lag 1 and 2 with the value of 0.341193 and 0.397281 and a t-value of 0.51195 and 0.58554 respectively. Similarly, the coefficient 
estimate for prime lending rate (PLR) was negatively signed and not significantly linked to real GDP when lagged both in first and second period. The PLR coefficient value was (-0.056965) with a t-value of (-0.09255) at lag 1 and the coefficient value of -0.256329 and t-value of -0.40833 at lag 2. Finally, the parameter estimate for deposit rate (DPR) was positively signed and not significantly related to real GDP when lag at one period. The coefficient has a positive value of 0.842714 with a t-value of 1.08954 but turned negative and significant with the value of -0.739319 as coefficient and -0.995113 as the t-value at lag 2.

However, a look at the VAR global statistic results shows that the observed degree of relationship between real economic output and the interest rate channels variables stood at an $\mathrm{R}$ squared of 0.783486 . This implies that about 78 percent of the variations in growth of the Nigeria economy were explained by changes in interest rate channel variables. This shows that the direct link from interest rate channel to growth of the Nigeria economy has historically been strong.

The results of the variance decomposition in Table 4 shows that short run shock to RGDP accounted for $100 \%$ variation of fluctuation in RGDP (own shock) and $0 \%$ from other variables in that period. The result also showed that the variation in RGDP as accounted for by its own shock happens to be the highest and varies from $100 \%$ in the first period to $81.27 \%$ over the 10 period horizons. Also in the short run i.e. period two, shock to RGDP account for $0.59 \%$ changes in fluctuations in monetary policy rate (MPR) and $1.49 \%$ in the long run that is the $10^{\text {th }}$ period. About $99 \%$ of variation in fluctuations in MPR is as a result of own shock in the first period. Also, in period two, a shock in RGDP account for $0.20 \%$ variations in fluctuation in TBR (Treasury Bill Rate), while $10^{\text {th }}$ period i.e. (long run), it account for $16.71 \%$ with $25.7 \%$ shocks as a result of own shock in the first period. RGDP shocks account for $0.24 \%$ variation of fluctuation in LDR in the short run and $1.11 \%$ in the long run with $30.3 \%$ being accounted for from own shock in the first period. Similarly about $0.24 \%$ changes in fluctuations in LDR are accounted by Real GDP shock in the first period and $1.70 \%$ at the long run while $64.9 \%$ being accounted for by its own shock. Finally, for DPR it also account for $0.01 \%$ variation in fluctuations in the short run and $0.37 \%$ on the long run while for its own shock it recorded $37.5 \%$ and $12.9 \%$ for both short and long run respectively.

Table-5.Vector autoregression estimates for credit channel

\begin{tabular}{|c|c|c|c|c|}
\hline Items & RGDP & CPS & CGO & $\overline{C S M}$ \\
\hline Lag 1 & $\begin{array}{l}0.690180 \\
(0.14350) \\
{[4.80973]}\end{array}$ & $\begin{array}{l}0.459879 \\
(0.00430) \\
{[1.21243]}\end{array}$ & $\begin{array}{c}0.000762 \\
(0.00140) \\
{[2.54544]}\end{array}$ & $\begin{array}{r}-0.082126 \\
(0.33406) \\
{[-0.24584]}\end{array}$ \\
\hline $\operatorname{Lag} 2$ & $\begin{array}{c}-0.209061 \\
(0.14368) \\
{[-1.45503]}\end{array}$ & $\begin{array}{l}-0.554997 \\
(0.00015) \\
{[-1.75550]}\end{array}$ & $\begin{array}{c}-0.000158 \\
(0.00139) \\
{[-0.11419]}\end{array}$ & $\begin{array}{r}-0.176417 \\
(0.31351) \\
{[-0.56271]}\end{array}$ \\
\hline Constant & $\begin{array}{l}6.812128 \\
(3.20003) \\
{[2.12877]}\end{array}$ & $\begin{array}{c}3.663073 \\
(1.61279) \\
{[2.27126]}\end{array}$ & $\begin{array}{c}144.7818 \\
(349.812) \\
{[0.41388]}\end{array}$ & $\begin{array}{r}2.308926 \\
(1.48328) \\
{[1.55663]}\end{array}$ \\
\hline R-squared & 0.783486 & & & \\
\hline Adj. R-squared & 0.667005 & & & \\
\hline $\begin{array}{c}\text { F-statistic } \\
\text { Prob } \\
\text { Log likelihood } \\
\text { Akaike AIC } \\
\text { Schwarz SC } \\
\text { Durbin Watson }\end{array}$ & $\begin{array}{c}13.50635 \\
0.000290 \\
-189.6974 \\
7.298088 \\
7.699555 \\
2.035670\end{array}$ & & & \\
\hline
\end{tabular}

Source: E-view 9.0 Output.

The VAR results of the relative statistics are summarized on Table 5. It can be seen that the parameter estimate for growth in credit to the private sector (CPS) has a short run positive and significant relationship with Real GDP at lag 1. It turned negative at lag 2. The variable recorded a coefficient 0.459879 and -0.554997 with a probability and standard error of $0.00015 \& 0.000430$ at t-value of 1.75530 and 1.21243 respectively.

Similarly, the coefficient estimate for growth in credit to the government (CGO) also had short run positive relationship with Real GDP. This is statistically significant at lag 1 but turned negative when it was lagged 2 . CGO as a variable of the credit channel recorded a coefficient of 0.000762 and -0.000158 at both lag 1 and 2 . The standard error stood at 0.00140 and 0.00139 with a t-statistics of 0.54544 and -0.24584 for both lag. Also, the parameter estimate for growth in credit to SMEs (CSM) has a negative short run relationship with Real GDP when lagged at period 1 and 2. CSM recorded a coefficient of -0.082126 and -0.176417 , a standard error of 0.33406 and 0.31351 and a t-value of -0.24584 and -0.56271 . However, the observed degree of relationship between the variables of credit channel and economic growth was quite high at an adjusted R squared of 0.667. By implication, about $67 \%$ of the variations in Real GDP were explained by changes in credit channel variables. This demonstrates a good fit as indicated by the F- statistic of 13.506. The log likelihood ratio, Akaike information criterion and Schwarz Bayesian criterion statistic all showed that the model has good forecasting power. Thus the credit channel of monetary policy transmission mechanism has short run relationship with Real GDP. Therefore, the null hypothesis of no significant short run relationship cannot be accepted in place of the alternative hypothesis.

The result of the variance decomposition analysis for credit channel as presented in Table 6 shows that changes in the variation in real GDP accounted by its own shock seem to be the highest and changes from $100 \%$ within the first period to $85.96 \%$ over ten (10) period horizons. For growth in credit to the private sector (CPS), the result also revealed that the variations in real GDP accounted for by credit channel variables are low and started from 0.000 in the first period for CPS, CGO, CSM and NDC to $2.15 \%, 0.18 \%, 0.45 \%$ and $1.29 \%$ in the second period to about $2.33 \%, 0.17 \%, 3.29 \%$, and $1.20 \%$ in the fourth period than $2.90 \%, 0.19 \%, 7.12 \%$ and $3.68 \%$ and $2.90 \%, 0.20 \%$, $7.23 \%$ and $3.71 \%$ in the ninth and tenth period horizon respectively. As regards credit to private sector (CPS), the variance decomposition result shows that changes in CPS accounted for by its own shock is the highest and changes from $99.7 \%$ in the period to $74.52 \%$ in third period to $73.73 \%$ in the tenth period. 


\begin{tabular}{|c|c|c|c|c|c|c|}
\hline Variance decomposition of RGDP: & & & & & & \\
\hline Period & S.E. & RGDP & CPS & CGO & CSM & NDC \\
\hline 1 & 8.513706 & 100.0000 & 0.000000 & 0.000000 & 0.000000 & 0.000000 \\
\hline 2 & 10.62898 & 95.91622 & 2.153178 & 0.187866 & 0.453195 & 1.289540 \\
\hline 3 & 10.97646 & 94.79788 & 2.093407 & 0.176474 & 1.722649 & 1.209589 \\
\hline 4 & 11.10055 & 93.00190 & 2.333663 & 0.173248 & 3.289624 & 1.201567 \\
\hline 5 & 11.27434 & 90.16023 & 2.763084 & 0.168374 & 4.918100 & 1.990212 \\
\hline 6 & 11.41178 & 88.00253 & 2.918916 & 0.170454 & 6.003359 & 2.904743 \\
\hline 7 & 11.48723 & 86.85575 & 2.930072 & 0.184259 & 6.613413 & 3.416508 \\
\hline 8 & 11.52235 & 86.33435 & 2.916123 & 0.194995 & 6.942033 & 3.612495 \\
\hline 9 & 11.53917 & 86.08811 & 2.907760 & 0.199433 & 7.123093 & 3.681599 \\
\hline 10 & 11.54812 & 85.95792 & 2.904956 & 0.200790 & 7.228336 & 3.707998 \\
\hline \multicolumn{7}{|l|}{ Variance decomposition of CPS: } \\
\hline Period & S.E. & RGDP & CPS & CGO & CSM & NDC \\
\hline 1 & 4.290857 & 0.228812 & 99.77119 & 0.000000 & 0.000000 & 0.000000 \\
\hline 2 & 5.606817 & 0.137677 & 86.00194 & 0.483241 & 0.716047 & 12.66109 \\
\hline 3 & 6.408449 & 0.105563 & 76.36918 & 0.478326 & 1.007384 & 22.03955 \\
\hline 4 & 6.675994 & 0.098216 & 74.52119 & 0.682125 & 0.953307 & 23.74516 \\
\hline 5 & 6.792062 & 0.103760 & 74.02347 & 0.813357 & 0.926071 & 24.13334 \\
\hline 6 & 6.847893 & 0.116362 & 73.89031 & 0.849597 & 0.946119 & 24.19761 \\
\hline 7 & 6.878504 & 0.128779 & 73.82853 & 0.861388 & 0.993735 & 24.18757 \\
\hline 8 & 6.895708 & 0.137957 & 73.78851 & 0.866216 & 1.051314 & 24.15601 \\
\hline 9 & 6.905732 & 0.144124 & 73.75700 & 0.868142 & 1.108895 & 24.12184 \\
\hline 10 & 6.911874 & 0.148307 & 73.73036 & 0.868699 & 1.160189 & 24.09244 \\
\hline \multicolumn{7}{|l|}{ Variance decomposition of CGO: } \\
\hline Period & S.E. & RGDP & CPS & CGO & CSM & NDC \\
\hline 1 & 930.6796 & 0.046527 & 0.279977 & 99.67350 & 0.000000 & 0.000000 \\
\hline 2 & 944.7250 & 0.064122 & 0.765088 & 96.73188 & 0.009046 & 2.429863 \\
\hline 3 & 949.6329 & 0.114879 & 0.983879 & 96.02844 & 0.447603 & 2.425198 \\
\hline 4 & 951.3423 & 0.170898 & 1.190525 & 95.68415 & 0.517420 & 2.437010 \\
\hline 5 & 952.0526 & 0.180696 & 1.253276 & 95.54227 & 0.588060 & 2.435696 \\
\hline 6 & 952.5048 & 0.183216 & 1.286119 & 95.45211 & 0.642363 & 2.436196 \\
\hline 7 & 952.8129 & 0.184456 & 1.303185 & 95.39059 & 0.686941 & 2.434831 \\
\hline 8 & 953.0378 & 0.185532 & 1.315494 & 95.34564 & 0.719145 & 2.434184 \\
\hline 9 & 953.1952 & 0.186436 & 1.324494 & 95.31418 & 0.741167 & 2.433727 \\
\hline 10 & 953.3040 & 0.187099 & 1.330946 & 95.29241 & 0.756209 & 2.433333 \\
\hline \multicolumn{7}{|l|}{ Variance decomposition of CSM: } \\
\hline Period & S.E. & RGDP & CPS & CGO & CSM & NDC \\
\hline 1 & 3.946292 & 0.009126 & 4.732927 & 1.051240 & 94.20671 & 0.000000 \\
\hline 2 & 4.837075 & 2.245935 & 9.670467 & 0.930410 & 85.65812 & 1.495064 \\
\hline 3 & 5.541914 & 2.699962 & 10.81289 & 0.711073 & 81.40366 & 4.372413 \\
\hline 4 & 5.906846 & 2.948474 & 12.67108 & 0.632347 & 79.79468 & 3.953413 \\
\hline 5 & 6.137277 & 2.988809 & 13.51381 & 0.587202 & 79.13922 & 3.770962 \\
\hline 6 & 6.290370 & 2.985850 & 14.03121 & 0.559595 & 78.77341 & 3.649936 \\
\hline 7 & 6.393698 & 2.980258 & 14.35869 & 0.542005 & 78.53396 & 3.585087 \\
\hline 8 & 6.464403 & 2.977546 & 14.59224 & 0.530361 & 78.35885 & 3.541006 \\
\hline 9 & 6.512655 & 2.977040 & 14.76261 & 0.522621 & 78.22946 & 3.508269 \\
\hline 10 & 6.545651 & 2.977037 & 14.88470 & 0.517451 & 78.13653 & 3.484277 \\
\hline \multicolumn{7}{|l|}{ Variance decomposition of NDC: } \\
\hline Period & S.E. & RGDP & CPS & CGO & CSM & NDC \\
\hline 1 & 48.71597 & 0.077010 & 10.60329 & 2.451312 & 8.633990 & 78.23439 \\
\hline 2 & 49.10961 & 0.754033 & 10.44652 & 2.960539 & 8.771397 & 77.06751 \\
\hline 3 & 49.51701 & 0.852704 & 10.42489 & 3.304459 & 8.930783 & 76.48717 \\
\hline 4 & 49.57541 & 0.860854 & 10.45235 & 3.300195 & 9.042889 & 76.34371 \\
\hline 5 & 49.63941 & 0.858643 & 10.50200 & 3.293769 & 9.098248 & 76.24734 \\
\hline 6 & 49.68093 & 0.857266 & 10.51992 & 3.290099 & 9.138086 & 76.19463 \\
\hline 7 & 49.70097 & 0.856608 & 10.52374 & 3.289081 & 9.158034 & 76.17254 \\
\hline 8 & 49.70973 & 0.856411 & 10.52373 & 3.288937 & 9.168294 & 76.16263 \\
\hline 9 & 49.71324 & 0.856382 & 10.52325 & 3.288918 & 9.173466 & 76.15799 \\
\hline 10 & 49.71480 & 0.856379 & 10.52287 & 3.288879 & 9.176207 & 76.15567 \\
\hline $\begin{array}{c}\text { Cholesky ordering: RGDP CPS CGO } \\
\text { CSM NDC }\end{array}$ & & & & & & \\
\hline
\end{tabular}

Source: E-view 9.0 output.

\section{Conclusion and Recommendations}

From the results, we conclude that the interest rate channel and the credit channel are significant channels for transmitting monetary policy actions in Nigeria. This is not a surprising outcome due to the fact that these channels significantly influences and promote growth of the economy. A good understanding of these channels through which monetary policy actions can be transmitted into the economy is very critical for a wide range of macroeconomic policy formulation and implementation. For instance in stabilizing macroeconomic output and prices, which monetary policy instrument can be put to work in the case of business cycle and high inflationary pressure, which monetary policy instruments are appropriate to tackle it. These and more other pertinent policy 
question should be examined in developing economies like Nigeria. Based on this, some very pertinent recommendations were offered from the empirical findings of this study as follows:

i Nigeria monetary authority should persistently adopt the use of changes in its monetary policy rate (MPR) as a policy strategy to effects changes in the credit supply and its accessibility by the productive sector of the economy. With such measures, the economy we experience changes in the credit market and the institutions. As it is through this mechanism, that the interest rate and credit channels would impact on the economy positively.

ii In periods of perceived down-turn in economic activity, the CBN should employ the expansionary monetary policy tool of lowering the MPR to stimulate the credit channel, it supply and accessibility with the view of stimulating output growth, enhance employment generation and to better the general wellbeing of the economy without losing sight of its commitment to sustaining confidence in the monetary and financial system.

iii To trigger growth through the credit channel, managers of the Nigeria economy should improve on financial regulatory reform while the country judicial system should be strengthen. As these reforms can help in tightening the credit worthiness of the potential borrowers on one hand and the volume of nonperforming loans reduce on the other hand as well as enhancing the bank asset quality which in turn fortify the credit channel of monetary policy transmission mechanism in Nigeria.

\section{Reference}

Bernanke, B.S. and M. Gertler, 1995. Inside the black box: The credit channel of monetary policy transmission. Journal of Economic Perspectives, 9(4): 27-48.Available at: https://doi.org/10.1257/jep.9.4.27.

Cecchetti, S.G., 1999. Legal structure, financial structure and the monetary policy transmission mechanism. National Bureau of Economic Research, Working Paper, No 7151.

Chileshe, P., F.Z. Mbao, B. Mwanza, L. Mwansa, T. Rasmussen and P. Zgambo, 2014. Monetary policy transmission mechanism in Zambia. Bank of Zambia Working Paper No 01.

Chimobi, O.P. and U.C. Uche, 2010. Money, price and output: A causality test for Nigeria. American Journal of Scientific Research, 8(1): 7887.

Chuku, C.A., 2009. Measuring the effects of monetary policy innovations in Nigeria: A Structural Vector Autoregressive (SVAR) Approach. Available from http://www.researchgate.net/publication/228272597_Measuring_the_Effects_of_Monetary_Policy [Accessed June 13, 2016].

Elbourne, A., J. de Haan, Kiviet and M.C. Bas, 2003. Financial structure and monetary policy transmission in transition countries. Journal of Comparative Economics, Elsevier, 34(1): 1-23.

Fasanya, I.O., A.B. Onakoya and M.A. Agboluaje, 2013. Does monetary policy influence economic growth in Nigeria. Asian Economic and Financial Review, 3(5): 635-646.

Ganev, G., K. Molnar, R. K. and W. P., 2002. Transmission mechanism of monetary policy in central and Eastern Europe. Centre for Social and Economic Research, Warsaw, Case Reports, No 52.

Harcourt, P., R. State and P. Harcourt, 2011. The impact of monetary policy on Nigeria's macroeconomic stability (1970 - 2009) Nenbee, S. G, 2(2): 174-183.

Hassan, A., 2015. Transmission mechanism of monetary policy in Nigeria: Evidence from VAR approach. Master of Science (Economics) Dissertation Submitted to the Institute of Graduate Studies and Research, Eastern Mediterranean University Gazimağusa, North Cyprus.

Ishioro, B.O., 2013. Monetary transmission mechanism in Nigeria: A causality test. Mediterranean Journal of Social Sciences, 4(13): 377388.Available at: https://doi.org/10.5901/mjss.2013.v4n 13p377.

Ismail, O., 2014. Does monetary policy influence economic growth in Nigeria? International Journal of Economic and Finance Management, $12(1): 1-32$.

Jhingan, M.L., 2011 . Monetary economics. 7th Edn., Delhi: Vrinda Publications Limited.

Juks, R., 2004. Monetary policy transmission mechanisms: A theoretical and empirical overview: The Monetary Transmission Mechanism in the Baltic States, Tallinn. Available http://eestipank.info/pub/en/dokumendid/publikatsioonid/seeriad/muuduuringud/2004/2.pdf?objId=533623.

Kujis, L., 2002. Monetary policy transmission mechanism and Inflation in the Slovak Republic. IMF Working Paper, No 80.

Mihov, I., 2001. Monetary policy implementation and transmission in the European monetary union. Economic Policy Review, $31(1)$ : $371-$ 406.

Ndekwe, E.C., 2013. An analysis of the monetary policy transmission mechanism and the real economy in Nigeria. Central Bank of Nigeria Occasional Paper No 43.

Nwosa, P.I. and M.O. Saibu, 2012. The monetary transmission mechanism in Nigeria: A sectorial output analysis,' International Journal of Economics and Finance, 4(1): 204-212.Available at: https://doi.org/10.5539/ijef.v4n 1p204.

Obafemi, F. and E. Ifere, 2015. Monetary policy transmission mechanism in Nigeria: A FAVAR approach. International Journal of Economics and Finance, 7(8): 93-103.Available at: https://doi.org/10.5539/ijef.v7n8p229.

Omolade, A. and H. Ngalawa, 2017. Monetary policy transmission mechanism and growth of the manufacturing sectors in Libya and Nigeria. Journal of Entrepreneurship, Business and Economics, 5(1): 67-107.

Taylor, J.B., 1995. The monetary transmission mechanism: An empirical framework. Journal of Economic Perspectives, 9(4): 11-26.Available at: https://doi.org/10.1257/jep.9.4.11.

Uchendu, O., 2009. Monetary policy management in Nigeria in the context of uncertainty. Bullion, Central Bank of Nigeria, 33(3): 1-6. 